Volume 4 Number 2 December 2020

\title{
People's Story Writing Strategy Using Kumon Learning Model Students of Indonesian Language and Literature Education Study Programs In STKIP PGRI Bangkalan
}

\author{
Sakrim \\ STKIP PGRI Bangkalan \\ Indonesian Language and Literature Education Study Program \\ sakrim@stkippgri-bkl.ac.id
}

\begin{abstract}
To improve the ability to write Madurese folklore for students of the Indonesian Language and Literature education program STKIP PGRI Bangkalan who can assess 23 students of this study as a solution. This study uses a classroom action approach. Technique data in research using test techniques. The results of the test data analysis by looking at the average value of improvement in the pre-action cycle, cycle I, and cycle II. The data analysis technique is done by adding up the scores from the indicators obtained from the students. In the pre-action activity cycle, the average value was $72.70 \%$ with a completeness of $35.36 \%$ with 8 students completing and 15 incomplete students. In the first cycle of action, the student's average score was 78.50 and the completeness only reached $74.63 \%$ with 16 complete students and 7 incomplete students. Meanwhile, in cycle II there were 20 students who had completed with a proportion of $94.72 \%$ of students who had not yet completed it as many as 3 students with a proportion of $7.20 \%$. The results of this study indicate that the increase in Madurese folklore for students.
\end{abstract}

Keywords: strategy, learning, kumon

\begin{tabular}{ll}
\hline Article History & Received : August $7^{\text {th }} 2020$ \\
& Revision : October $11^{\text {th }} 2020$ \\
& Publication : Dec $30^{\text {th }} 2020$ \\
\hline
\end{tabular}

\section{INTRODUCTION}

Writing folklore is a communication skill activity performed by a person indirectly in exporting ideas and ideas to the public. Writing folk tales is an activity that tries to unravel natural phenomena that occur in certain areas. The twists and turns in social and culture are summarized to provide an explanation for the reader. To export social and cultural phenomena in written form, competency standards must be mastered. These competency standards must be mastered by students to improve and practice writing skills, both in theory and in practice, the knowledge that describes writing, such as the general guidelines for Indonesian spelling (PUEBI), the knowledge that parses the sentence (syntax), the knowledge that describes existing discourse must be understood for writers especially student. 
The general definition of writing was conveyed by Kusumaningsih, et al. Stated that "Writing is an activity of delivering messages.... (Melly Maulidah Fitriani, 2020: 94). Writing an activity conveys messages from natural phenomena that are found or researched. Meanwhile, Enre "writing is one of the instruments that is suitable for learning because it will train students in their minds (Everhard Markiano Solissa and Lesly Chriselya Wattimury, 2020: 218).

Agus Tinus (2015) emphasizes that folklore is a reflection of life that is obtained through reflecting on the imagination and creativity of writing so that it produces beautiful works that can be enjoyed by readers or literary connoisseurs. Folklore as a description of life is certainly full of values and norms that exist in an educational society. So a literary work especially has weight if it contains various educational values that are beneficial to its readers. Folklore as a form of literary work can provide readers with reflection, appreciation, and actions regarding the values of life contained in the story. These values reveal praiseworthy or disgruntled actions, which way of life is adhered to or shunned, and what matters are high in moral, social, religious, and cultural terms in human life.

There are many problems faced by students in writing, especially writing folk tales, including inexperience and low knowledge in the field of writing, lack of motivation, and less creative application of learning. Students tend to be astonished because they are unable to narrate and argue for phenomena that exist in the social environment. Got two paragraphs and three paragraphs, students already feel out of ideas and ideas. This is also emphasized by (Iskandarwassid \& Sunendar ... Writing skills are considered a language skill that is quite difficult to learn. Writing skills are skills that have a high level of difficulty for learners compared to the other three language skills "(Iskandarwassid \& Sunendar, Tri Indri Hardini et al. (2020: 122).

In order for maximum learning outcomes, it is necessary to have variants in the learning process. The use of creative learning models as a solution for students who are less motivated to write. A learning model that inspires and enhances written competencies for students, which can be written in folklore is the Kumon learning model. The Kumon learning model is a learning model that links skills, concepts and personal work. As well as maintaining a pleasant atmosphere for students. The Kumon learning model according to Huda (in Sutrisno et al, 2015: 25) the Kumon learning model emphasizes the individual work system, which is based on the differences in each student who has different abilities. This CUMON learning model has been used by developed countries in building public educational institutions for the past 50 years and continues to develop until now.

In line with Shiba's opinion, the Kumon learning model which originated from Japan is considered effective in improving children's mathematics understanding at school. The Kumon learning model emphasizes activities on understanding each student, so that students can explore their 
potential and develop their understanding maximally. Kumon learning does not only teach how to count but can also improve students' ability to focus more on doing something and self-confidence (Karyanti and Komarudin 2017: 90).

Based on the above background, this research was carried out to prove the effectiveness of the folklore writing strategy using the Kumon learning model for students of the Indonesian Language and Literature education program STKIP PGRI Bangkalan? With the hope of becoming an alternative and variety of learning models in improving writing skills, especially in writing folk tales.

\section{METHODS}

The research was conducted using the classroom action method. This study seeks to analyze, systematically disentangle, and collaborate on learning plans on lecturer performance and the existing interactions between lecturers and students (Arikunto, 2007). This research was conducted at STKIP PGRI Bangkalan. The subjects of this study were 4 th semester students of the Indonesian Language and Literature Education study program at STKIP PGRI Bangkalan and the object was the ability to write Madurese folklore, the 4th semester students of the Indonesian Language and Literature Education study program at STKIP PGRI Bangkalan using the Kumon learning model strategy. This research was conducted in two cycles, each cycle following the steps of classroom action research that are generally carried out in research including; research plan, implementation, observation, and reflection. In each cycle, an evaluation of the action is carried out according to the results of the actions that have been carried out previously, this is to seek the results achieved at the very maximum and accurate stage. Data were collected directly using written test techniques. Then the data were analyzed to determine the results of individual student learning by adding up the scores of each indicator.

\section{RESULTS AND DISCUSSION Result}

This research was conducted in semester 4 of the Indonesian Language and Literature Education study program at STKIP PGRI Bangkalan with 23 students consisting of 10 boys and 13 girls. The value action was obtained $\geq 75$ or completed by 8 people with a percentage of $35.36 \%$. Furthermore, there are 15 students who get a score of $\leq 75$ or have not yet completed it with a percentage of $68.60 \%$. The average overall score in the preclass action was 72.70 . In more detail, the results of the pre-action class activities can be seen in the following table: 
Table 1. Pre-action

\begin{tabular}{|c|c|c|c|c|c|}
\hline Implementation & $\begin{array}{l}\text { The number } \\
\text { of students }\end{array}$ & & & & \\
\hline & & \multirow{2}{*}{$\begin{array}{l}\text { Completed } \\
\text { The } \\
\text { number of } \\
\text { students }\end{array}$} & & \multirow{2}{*}{$\begin{array}{l}\text { Not complete } \\
\text { The } \\
\text { number of } \\
\text { students }\end{array}$} & \\
\hline & & & $\%$ & & $\%$ \\
\hline Pre-action & 23 & 8 & $35,36 \%$ & 15 & 68,60 \\
\hline
\end{tabular}

Cycle I

The first cycle action of the Kumon model has begun to be applied to students, an increase in the learning process has begun to be seen, as evidenced by the fact that students look a little active when invited to communicate in the learning process and also look more fun. The average score in the first cycle, students only achieved 78.50. Judging from the results of the research cycle I that was complete or got a value of $\geq 75$ as many as 16 people with a percentage of $74.63 \%$. Meanwhile, there were 7 students who got a score of $\leq 75$ who had not completed it with a percentage of $29.16 \%$. The details of the first cycle of the results of teaching and learning activities can be seen in the following table:

Table 2. Cycle I

\begin{tabular}{|c|c|c|c|c|c|}
\hline \multirow[t]{2}{*}{$\begin{array}{l}\text { Implementation } \\
\text { of action }\end{array}$} & \multirow[t]{2}{*}{$\begin{array}{l}\text { The } \\
\text { number } \\
\text { of } \\
\text { students }\end{array}$} & Completed & \multicolumn{3}{|c|}{ Not complete } \\
\hline & & $\begin{array}{c}\text { The } \\
\text { number of } \\
\text { students }\end{array}$ & $\%$ & $\begin{array}{c}\text { The } \\
\text { number of } \\
\text { students }\end{array}$ & $\%$ \\
\hline Cycle I & 23 & 16 & $74,63 \%$ & 7 & 29,16 \\
\hline
\end{tabular}

Cycle II

Actions in the second cycle of students in writing Madurese folklore also experienced an increase, independently students were able to write Madurese folklore, their active enthusiasm, enthusiasm, and creativity were also increasingly visible in pouring ideas and ideas so that the atmosphere could be fun in learning. Writing Madurese folklore, students feel it is not difficult. When viewed from the learning process, it can be interpreted that the 
application of the Kumon learning model is an effort to improve the ability to write the right choice of Madurese folk tales. This agrees with the understanding of Anwar (2012: 4) who says that the Kumon learning model emphasizes individual independence, in this case for students to solve problems, students are required to be proficient in completing tasks properly according to their own abilities. Through achieving targets with their own abilities, children will feel joy and satisfaction in learning. The results in cycle II, which get a value of $\geq 75$ or complete are 20 people with a percentage of $94.72 \%$. Meanwhile, there were 3 students who got a score of $\leq 75$ or had not yet completed it with a percentage of $7.20 \%$ with an average score of students reaching 81.90. Details of the results in cycle II in teaching and learning activities can be seen in the following table:

Table 3. Cycle II

\begin{tabular}{|c|c|c|c|c|c|}
\hline \multirow{2}{*}{$\begin{array}{l}\text { Implementation } \\
\text { of action }\end{array}$} & \multirow{2}{*}{$\begin{array}{l}\text { The } \\
\text { number } \\
\text { of } \\
\text { students }\end{array}$} & Completed & \multicolumn{3}{|c|}{ Not complete } \\
\hline & & $\begin{array}{c}\text { The } \\
\text { number of } \\
\text { students }\end{array}$ & $\%$ & $\begin{array}{c}\text { The } \\
\text { number of } \\
\text { students }\end{array}$ & $\%$ \\
\hline Cycle II & 23 & 20 & $94,72 \%$ & 3 & 7,20 \\
\hline
\end{tabular}

Improvements continued to be made in cycle II, looking at the deficiencies that occurred in the previous cycle, namely the pre-action cycle and the first cycle, so that the students' ability to write Madurese folk tales actually increased. The following is presented from all cycles, namely the preaction cycle, the first cycle, and the second cycle which shows an increase in student abilities:

Table 4. Improving the ability of students from all cycles

\begin{tabular}{|c|c|c|c|c|c|}
\hline \multirow{2}{*}{$\begin{array}{l}\text { Implementation } \\
\text { of action }\end{array}$} & \multirow{2}{*}{$\begin{array}{l}\text { The } \\
\text { number } \\
\text { of } \\
\text { students }\end{array}$} & Completed & \multicolumn{3}{|c|}{ Not complete } \\
\hline & & $\begin{array}{c}\text { The } \\
\text { number of } \\
\text { students }\end{array}$ & $\%$ & $\begin{array}{c}\text { The } \\
\text { number of } \\
\text { students }\end{array}$ & $\%$ \\
\hline Pre-action & 23 & 8 & $35,36 \%$ & 15 & 68,60 \\
\hline Cycle I & 23 & 16 & $74,63 \%$ & 7 & 29,16 \\
\hline
\end{tabular}


Volume 4 Number 2 December 2020

\begin{tabular}{llllll}
\hline Cycle II & 23 & 20 & $94,72 \%$ & 3 & 7,20 \\
\hline
\end{tabular}

\section{Discussion}

Each Cycle and Between Cycles

Of the 23 students data obtained during the pre-action, 8 were completed with a percentage of $35.36 \%$, while 15 students who did not complete the study with a percentage of $68.60 \%$, the average score obtained in the pre-action was 72.70 . Whereas in cycle I the $85 \%$ completeness requirements in classical learning activities have not been achieved and are not yet complete. Students getting a score of $\geq 75$ only reached $74.63 \%$. Based on these results, it is necessary to proceed to cycle II. The second cycle of students who completed were 20 students with a percentage of $94.72 \%$, students who had not completed were 3 students with a percentage of $7.20 \%$. The results of this study indicate that there is an increase in the writing of Madurese folklore for students.

Agree with Hanif Himawati. 2014: 56) in the results of his research the application of the Kumon learning method assisted by the "General Journal Training Module" module shows an increase in learning outcomes. This is indicated by an increase from cycle I to cycle II. Not in line with the opinion (Eksan Sutrisno et al. 2015: 29) the results of the study using the combination of the Kumon learning model and the team games tournament produced ineffective results because there was no influence between activeness and process skills on learning achievement and there was no significant difference between the research models. and teachers. This can be caused by several factors, including (1) The questions used by the researcher are too many easy questions and too few moderate and difficult questions so that these questions cannot tell whether students are smart or not, (2) The researcher is not perfect in applying the model Learning Kumon and TGT based on Character Education into classroom learning, (3) Researchers lack the attractiveness of being able to make students active and have process skills as expected, and there may be many other factors that are not realized by researchers, causing research become ineffective. Based on the description of the discussion of the results of this study the researcher does not recommend using the learning model used. Intercycle Discussion

Pre-action activities with completeness of $35.36 \%$ with the number of students completing as many as 8 students and those who did not complete as many as 15 students the average score of students obtained was $72.70 \%$. In the first cycle of action, the average score was 78.50 and completeness only reached $74.63 \%$ with 16 students who completed and 7 students who did not complete. Whereas in cycle II the average score reached 81.90 with 20 students completing and 3 incomplete students. So, from cycle I to cycle II increased by $22.89 \%$. This increase can be seen in the following formula: 


\section{$\underline{\mathrm{P}=\mathrm{R} 2-\mathrm{R} 1 \times 100 \%}$}

R1

Information:

$\mathrm{P}=$ percentage increase in ability

$\mathrm{R} 1$ = average value before action

$\mathrm{R} 2$ = the average value after the action cycle I and cycle II

Based on the formula above, it can be obtained the results of the R1 study of 72.70 and the R2 value of 79.25. The value of R2 is obtained from adding up the average value of cycle I, namely 72.70 and cycle II of 81.90 then divided by two, the result is 78.28. The next step is to enter the two values, namely R1 of 72.70 and R2 of 79.25, then divided by the R1 value of 72.70 and multiplied by 100 , so that a $9.08 \%$ hassil is obtained. When compared between the pre-action cycle and the end of cycle II, there was an increase in the average score of $59.38 \%$, while the increase in the average score of students' ability from pre-action to action cycle I and cycle II was 38.50\%, it was known that 20 students out of 23 students, then the percentage of completeness reached 94.72\%.

Based on the action hypothesis, it can be said that the use of the kumon model can improve the students' ability to write Madurese folk tales. Zainurrahman emphasized that writing skills have a very important role in everyday life. Books, articles, news, stories, announcements, and reports are examples of familiar forms of written language products in life. Writing skills are an absolute requirement for someone to be involved in various fields of activity. This implies that writing skills have a very important role in everyday life (Jimat Susilo and Veronica Endang Wahyuni: 62).

The maximum results of writing skills using the Kumon learning model can be seen from the results of the completeness value at the end of the study of $94.72 \%$. Students feel the learning atmosphere becomes more effective, comfortable, and fun while still understanding the potential and abilities of students in writing Madurese folklore. This means that the lecturer has guided students effectively and appropriately, linking concepts, skills and doing assignments individually according to their respective abilities. This is in line with the opinion of Anwar (2012: 5) which states that the Kumon learning model given to students individually while still providing the right portion level will develop students' abilities or potential in learning. This model can also increase job dexterity, thinking skills, and self-confidence.

\section{CONCLUSION}

Based on the data that has been analyzed along with the discussion of the results of the research in general, it can be concluded that with the application of the Madurese folklore writing strategy with the Kumon learning model in Indonesian Language and Literature education program students, it can be increased, while the specific conclusions in this study are: the student's ability to write. Madurese folklore can be improved with the Kumon learning 
model, because with the Kumon learning model the learning atmosphere becomes more effective, comfortable, and fun for students. This can be seen from the average pre-action test score of 72.70, the first cycle average of 78.50, and the average test score of the second cycle was 81.90.

The data obtained during the pre-action from 23 students, who completed 8 students with a percentage of $35.36 \%$, while the students who did not complete were 15 students with a percentage of $68.60 \%$, the value obtained from the average pre-action cycle was 72.70 . Whereas in cycle I the $85 \%$ completeness requirements in classical learning activities have not been achieved and are not yet complete. Students getting a score of $\geq 75$ only reached $74.63 \%$. Based on these results, it is necessary to proceed to cycle II. The second cycle of students who completed were 20 students with a percentage of $94.72 \%$, students who had not completed were 3 students with a percentage of $7.20 \%$. The results of this study indicate that there is an increase in the writing of Madurese folklore for students.

\section{REFERENCES}

Agus Tinus. (2015). Journal of Humanika No. 15, Vol. 3, December 2015 / ISSN 1979-8296. Retrieved on 29 accessed November 2020file://C:/Users/SA\%20KRIM/Downloads/611-1625-1-PB.pdf

Anwar. (2012). Learning System Planning. Bandung: Alfabeta.

Arikunto, Suharsimi. (2007). Classroom Action Research. Jakarta: Earth Literacy.

Eksan Sutrisno et al. Unimus Journal. Retrieved 29 November 2020 fromfile:///D:/Jurnal\%202020/artikel\%20kumon.pdf

Everhard Markiano Solissa and Lesly Chriselya Wattimury. (2020). Journal of stylistics. $\quad$ Retrieved December 2020 fromfile://C:/Users/SA\%20KRIM/Downloads/4779-15025-1-PB.pdf

Hanif Himawati. Economics Education Analysis Journal. accessed on 29 November 2020 from file://C:/Users/SA\%20KRIM/Downloads/3146Article\%20Text-6186-1-10-20140412.pdf

Jimat Susilo and Veronica Endang Wahyuni. (2019). Ahmad Dahlan Bahastra University. $\quad$ Retrieved $29 \quad$ November 2020 fromfile:///C:/Users/SA\%20KRIM/Downloads/13573-38469-2-PB.pdf

Tri Indri Hardini et al. (2020). Journal of Language and Literature Education (UPI) November 29, 2020 from file://C:/Users/SA\%20KRIM/Downloads/25977-56773-1-PB.pdf

Karyanti and Komarudin. 2017. Proceedings of the National Seminar on Mathematics and Mathematics Education 2017. Accessed on November 28, 2020 from file:///C:/Users/SA\%20KRIM/Downloads/25-55-1SM.pdf 
Fitriani, Melly Maulidah (2020I. Journal of Language Studies, Indonesian Literature, and Learning. Retrieved 3 December 2020 from file://C:/Users/SA\%20KRIM/Downloads/14741-42945-1-SM.pdf

Sutrisno, Eksan. Et al. (2015). Effectiveness of Combining Kumon Learning Model and Teams Games Tournament Based on Character Education on Students' Learning Achievement in Statistics Class VII.Rembang.JKPM. Vol. 2, No.2: pp. 25-30 